\title{
«ОСОБЛИВІ ДІТИ» В УМОВАХ ОСОБЛИВОГО НАВЧАЛЬНОГО РОКУ
}

\author{
Наукова доповідь на веб-конференції «Учені НАПН України - українським \\ вчителям», 27 серпня 2020 p.
}

https://doi.org/10.37472/2707-305X-2020-2-2-12-4

\section{ЗАСЕНКО}

\section{В'ячеслав Васильович}

доктор педагогічних наук, профресор, дійсний член (академік) НАПН України, директор Iнституту спеціальної педагогіки і психології імені Миколи Ярмаченка Начіональної академії педагогічних наук України, м. Київ, Україна

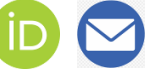

\section{ПРОХОРЕНКО}

Леся Іванівна

доктор психологічних наук, старший науковий співробітник, заступник директора з наукової poбomu IHcmumymy спеціальної педагогіки $і$ психології імені Миколи Ярмаченка Начіональної академії педагогічних наук України, м. Київ, Україна

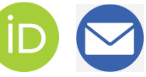

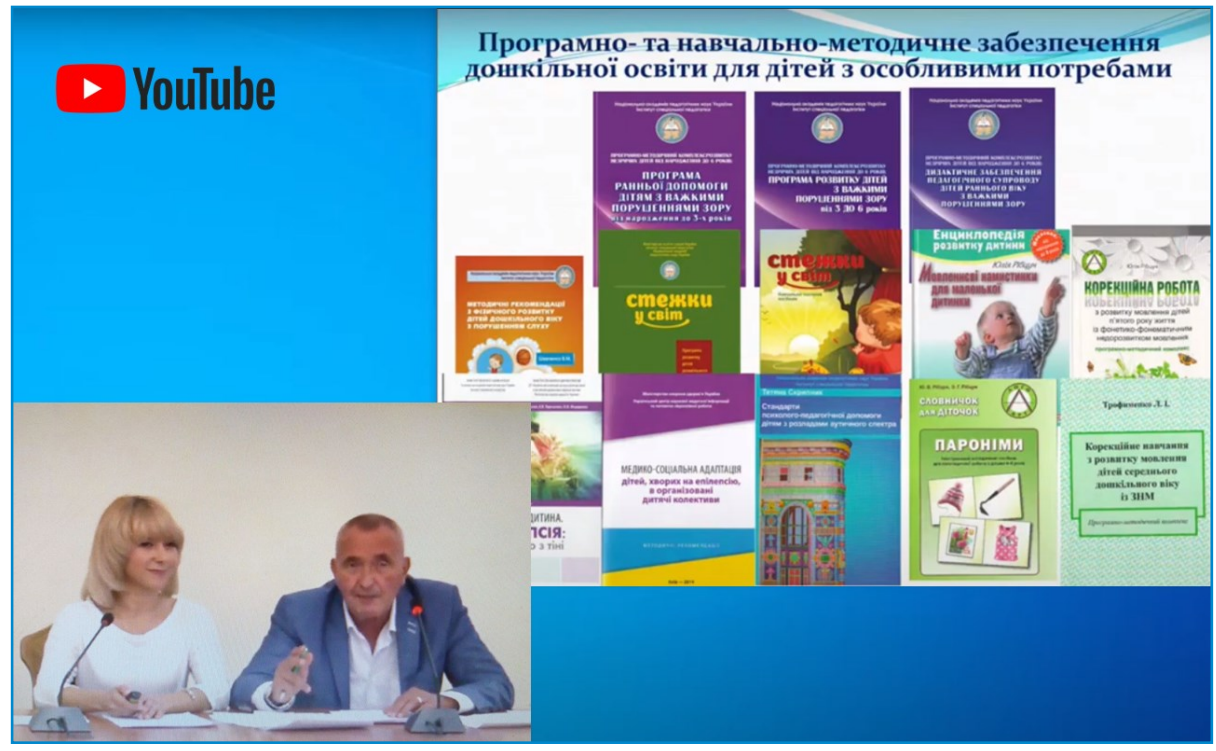

Анотація. Стисло окреслено загальні аспекти реформування освіти осіб із особливими потребами в Україні, розкрито ключові иляхи модернізації та охарактеризовано позитивні зрушення в освітній галузі. у доповіді зазначено, що Україна реорганізовує освітню систему для приведення ї̈ у відповідність з вимогами ринкової економіки та відкритого демократичного суспільства щодо забезпечення рівного доступу до якісної освіти для всіх дітей із особливими освітніми потребами. Сенс освіти розглядається як основний інструмент трансформації усієї системи, включаючи спеціальну освіту, на принципах компетентності. 3 точки зору компетентності конкретизація кількості шкільних предметів не є метою спеціальної освіти. Натомість суть полягає у визначенні результатів, які є вагомими на національному рівні і відображаються, зокрема, у державних стандартах, що впроваджуються в Україні. Охарактеризовано основні підходи і складові Концепції Нової української школи та визначено їх вплив на реформування системи освіти осіб з особливими потребами. Окреслено коло проблемних питань психолого-педагогічного та корекційно-розвивального супроводів дітей із особливими потребами, що потребують нагального вирішення.

Ключові слова: реформування освітньої галузі; Інститут спеціальної педагогіки і психології імені Миколи Ярмаченка НАПН України; діти з особливими освітніми потребами.

Реалізація конституційних прав на освіту для усіх осіб, незалежно від стану здоров'я та особливих потреб, є одним із пріоритетних напрямів діяльності держави, що відображено у законах України: «Про внесення змін до законодавчих актів з питань загальної середньої та дошкільної освіти щодо організації навчально-виховного процесу» (2010); «Про внесення змін до деяких законів України про освіту щодо організації інклюзивного навчання» (2014); «Про освіту» (2017). Ці та інші законодавчі та нормативно-правові документи прийнято для реалізації права вибору 
учнями закладу освіти та форми навчання за місцем проживання із забезпеченням усіх необхідних для цього умов.

У сучасних реаліях важливе значення для осіб із особливими потребами має дистанційна освіта, яка є чи не єдиною можливістю подолання соціальної ізоляції, включення у суспільне й соціально-економічне життя, формування власного повноцінного соціального статусу тощо.

Нинішній навчальний рік не просто особливий, а винятковий (у негативному сенсі), подібних якому не було, очевидно, з часів світових воєн. Від самого початку навчального року, від його організації, стану і якості навчально-методичного забезпечення, форм і технологій подачі матеріалу учням залежать наявність і кількість прогалин у їхніх знаннях, які на відміну від фінансових чи моральних втрат, залишаться на все життя.

Найперше це стосується дітей із особливими освітніми потребами, для яких, зазвичай, у спеціальних чи інклюзивних закладах освіти, окрім навчання, організовано системний психологопедагогічний супровід і, що важливо, корекційнорозвивальну роботу.

Тож, зважаючи на зазначене, вчені Інституту спеціальної педагогіки і психології імені Миколи Ярмаченка НАПН України (далі - Інститут), як, до речі, і вся Академія, ні на день не припиняючи роботи, максимально активізувалися, переглянули свої можливості, плани роботи і зосередили увагу саме на дистанційних формах подання навчального матеріалу і проведення просвітницьких заходів, дотримуючись, безумовно, нових державних стандартів і решти положень Нової української школи.

Принагідно зазначимо, що за результатами першого етапу моніторингу реформи «Нова українська школа», проведеного МОН України, позитивно ставиться до такої роботи 51\% батьків учнів загальноосвітніх шкіл, 55\% - спеціалізованих і спеціальних і 81\% - пілотних (МОН України, 2020a).

Останнім часом МОН України оприлюднило кілька нормативних документів, зокрема додаток до листа МОН України «Інструктивно-методичні матеріали щодо порядку підготовки закладів освіти до нового навчального року та опалювального сезону з питань цивільного захисту, охорони праці та безпеки життєдіяльності» від 29 липня 2020 р. № 1/9-406 і лист «Щодо організації роботи закладів загальної середньої освіти у 2020/2021 навчальному році» від 5 серпня 2020 р. № 1/9-420.
У цих документах йдеться, зокрема, про те, що на початку начального року рекомендується виявити рівень опанування учнями навчального матеріалу, який вони засвоювали під час карантинних обмежень самостійно або з використанням технологій дистанційного навчання. Потрібно визначити, чи необхідне повторення цього матеріалу, а також спланувати, систематизувати та узагальнити навчальний матеріал, активізувати окремі теми, передбачити визначення диференційованих навчальних завдань із урахуванням рівня засвоєння попереднього матеріалу учнями тощо (МОН України, 2020b; МОН України, 2020с).

Слід зазначити, що відповідно до Концепції Нової української школи (Кабінет Міністрів України, 2016) у практику впроваджено науковометодичне забезпечення навчання дітей з порушеннями інтелектуального розвитку (вперше в Україні розроблено Типові освітні програми для 1, 2, 3 класів для навчання дітей з інтелектуальними порушеннями та Критерії оцінювання навчальних досягнень учнів початкової школи).

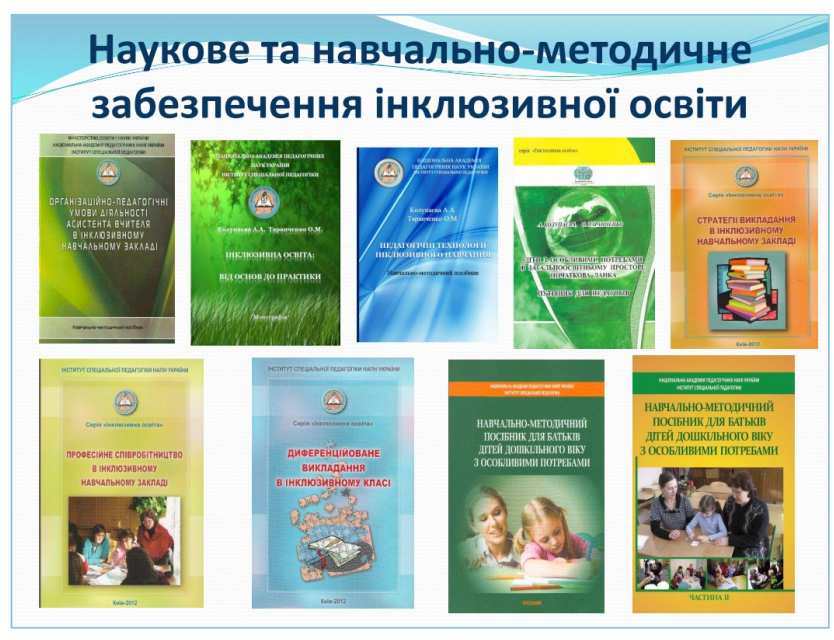

Відповідно до постанови Кабінету Міністрів України «Про затвердження Державного стандарту початкової освіти» від 21 лютого 2018 р. № 87, що передбачає втілення Концепції Нової української школи, в Інституті обґрунтовано і розроблено модель стандартизації навчальнометодичного забезпечення навчання молодших школярів із тяжкими порушеннями мовлення відповідно до нового Державного стандарту початкової освіти, а також підготовлено низку підручників.

Уперше в історії навчання дітей із порушеннями слуху завдяки співпраці Інституту з Українським товариством глухих, Об'єднанням нечуючих педагогів до освітнього процесу спеціальних закладів освіти для дітей із порушеннями слуху 


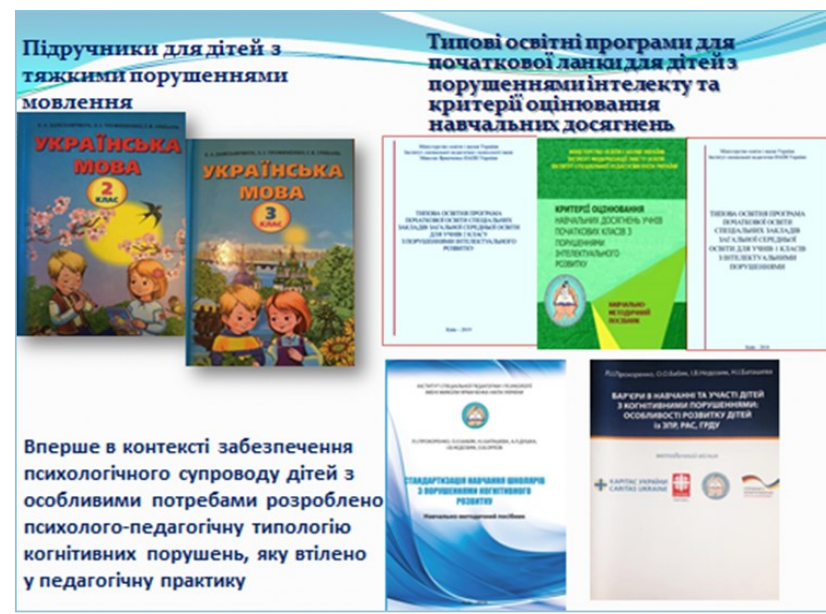

було введено навчальний предмет «Українська жестова мова». Фахівці Інституту розробили перші навчальні програми для підготовчого, 112 класів, а також навчально-методичні посібники для учителів жестової мови.

\section{Українська жестова мова}
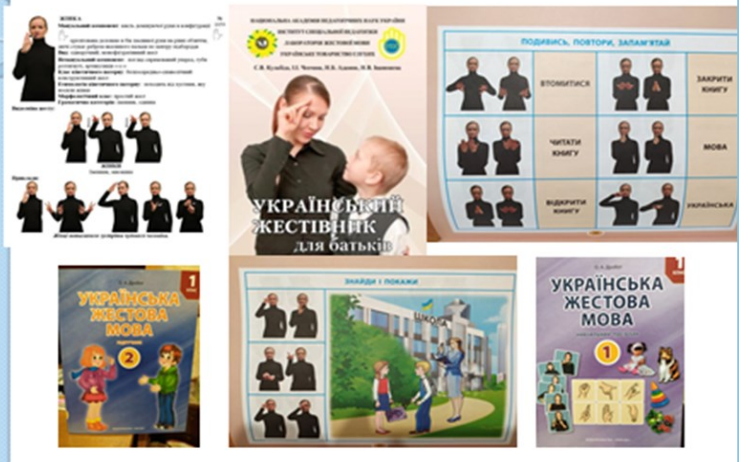

Упроваджено в освітню практику «Жестівник української жестової мови» та «Технології білінгвального навчання глухих та слабкочуючих». Триває підготовка підручників з цього предмета.

Інститут у тісній співпраці з Українським товариством глухих, враховуючи низку міжнародних нормативних актів, розробив законопроєкт «Про українську жестову мову», положення якого увійшли до статей 2, 4 Закону України «Про забезпечення функціонування української мови як державної» (2019), за якими вперше офіційно визнано статус української жестової мови на теренах нашої держави.

Принципово важливою $€$ корекційнорозвивальна робота з дітьми, які мають особливі освітні потреби, зокрема:

- модернізовано зміст корекційно-розвивальної роботи з подолання порушень мовленнєвого розвитку, що відображено у «Програмі з корекційно-розвивальної роботи для закладів загальної середньої освіти (для дітей з тяжкими пору- шеннями мовлення, 1-4 класи)», Програмі з корекційно-розвивальної роботи «Корекція розвитку» для закладів загальної середньої освіти (для дітей з тяжкими порушеннями мовлення, 1-4 класи)»;

- розроблено корекційно-розвивальні технології навчання молодших школярів із комплексними порушеннями (порушення інтелектуальної та рухової сфер розвитку), які представлено авторськими програмами з психофізичного розвитку («Корекція розвитку (базова)», а також авторськими модульними програмами, що доповнюють базову програму й спрямовані на розвиток і корекцію рухової сфери, сенсорних функцій, розширення уявлень про навколишній світ, розвиток пізнавальної діяльності, корекцію мовленнєвого розвитку, психокорекцію особистості;

- розроблено авторські інтегративно-модульні програми психосоціального розвитку («Розвиток психомоторики та сенсорних процесів», «Азбука творчості», «Цікавий світ Монтессорі», «Музичні краплинки»); розвитку мовлення («Розвиток мовлення», Методики ТАН-Содеберг); ритміки («У світі ритмів», «Театральна логоритміка», «Барабанотерапія»); соціально-побутового орієнтування («Соціально-побутове орієнтування»);

- уперше розроблено Типологію когнітивних порушень у дітей;

- розроблено Технологію корекційнорозвивального навчання дітей 3 розладами аутистичного спектра.

Впроваджено в практику навчання і виховання дітей із порушеннями зору адаптивні та авторські підручники для незрячих дітей шрифтом Брайля, корекційні та навчальні програми, навчальнометодичні посібники, методичні рекомендації.

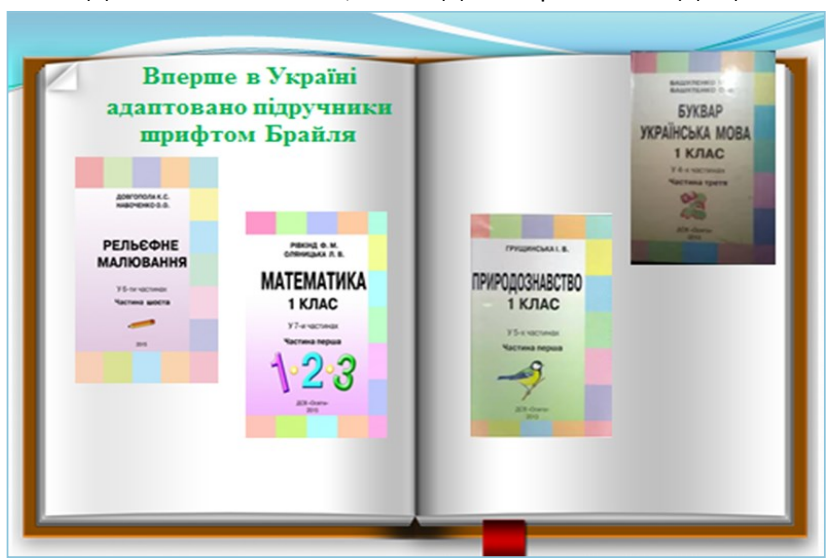

Важливий сучасний напрям або аспект досліджень і навчально-методичного забезпечення інклюзія. В Україні спостерігається стала динаміка зростання чисельності учнів в інклюзивних класах, кількості асистентів учителя тощо. 
Тож, на допомогу практикам розроблено і впроваджено комплект посібників «ннклюзивне навчання за нозологіями: «Дитина із труднощами у навчанні», «Батькам дітей з РАС», «Гіперактивна дитина», «Дитина з порушенням зору», «Дитина із затримкою психічного розвитку», «Дитина 3 порушенням слуху», «Дитина з порушенням розумового розвитку», «Дитина з церебральним паралічем», «Дитина із синдромом Дауна», «Технології навчання дітей з ООП в умовах загальноосвітнього середовища», «Путівник для педагогів та батьків дітей з ООП», «Діти з ООП в загальноосвітньому просторі», «Асистент вчителя у закладі 3 інклюзивною формою навчання», «Педагогічні технології інклюзивного навчання» та ін.

Утім, донині лишаються виклики на шляху поступу інклюзивної освіти в Україні, серед яких можна виділити:

- удосконалення системи надання державної підтримки особам з особливими освітніми потребами;

- архітектурна недоступність закладів освіти (одна із «застарілих» проблем);

- неготовність певних педагогічних працівників до роботи з учнями з особливими освітніми потребами;

- відсутність сучасних програм з інклюзивного навчання для закладів вищої освіти та інститутів післядипломної освіти;

- непоінформованість батьків дітей із особливими освітніми потребами про альтернативні можливості отримання освіти їхніми дітьми;

- необізнаність щодо успішного вітчизняного чи провідного зарубіжного досвіду роботи з учнями з особливими освітніми потребами;

- освітні програми недостатньо орієнтовні на формування компетентностей, необхідних для подальшого самостійного життя людини з особливим освітніми потребами.

Слід наголосити, що всі пропоновані навчально-методичні матеріали розроблялися на основі компетентнісного, індивідуального підходів і акцент робився на формуванні в учнів саме, так званих, «м'яких» навичок - критичного мислення, лідерства, уміння керувати емоціями. До речі, під час проведеного МОН України моніторингу щодо реформи «Нова українська школа» з'ясувалося, що, на думку дорослих, у шкільному житті їхніх дітей найбільше не вистачає завдань саме з формування "м'яких» навичок (МОН України, 2020a).
Варто зауважити, що в умовах особливого навчального року, який зумовлений уведенням карантинного режиму в країні, спричиненого наслідками пандемії COVID-19, надзвичайно важливо розробити дистанційну модель психологопедагогічного супроводу дітей із особливими потребами і їхніх родин. У цьому контексті Інститут розробляє матеріали дистанційного психологопедагогічного супроводу та надає інформаційні матеріали педагогам, психологам і батькам.

Проведено чимало дистанційних заходів (вебінари, відео, аудіо, файли, консультації, тренінги та ін.) щодо підготовки фахівців до надання психологічної допомоги сім'ям, які виховують дітей із особливими потребами.

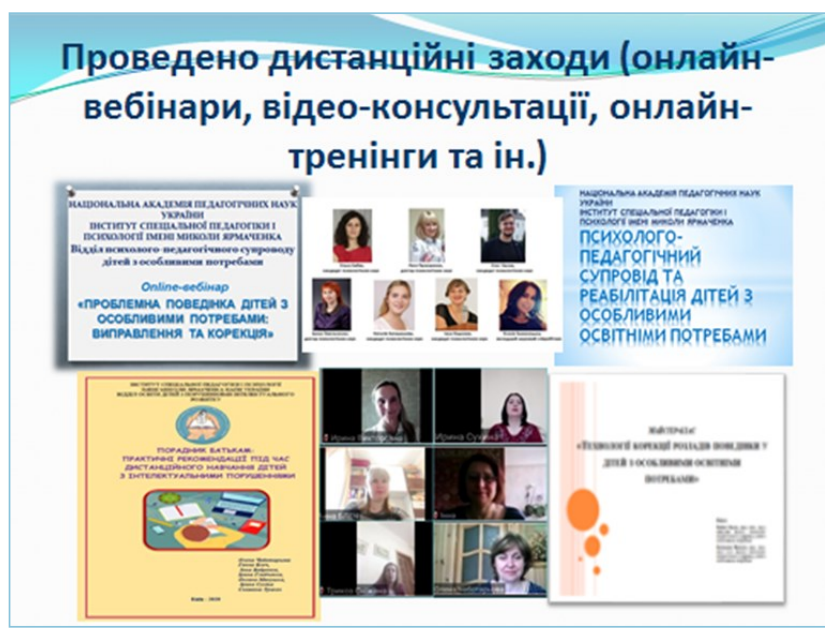

Водночас більшість учителів хвилюють питання організації онлайн-навчання дітей із особливими потребами. Тож, вчені Інституту розробили і впровадили (переважно через соціальні мережі) методичні матеріали інформативного і просвітницького характеру для педагогів, психологів і батьків: "Дистанційне навчання дітей з порушеннями слуху»; «Порадник батькам: практичні рекомендації під час дистанційного навчання дітей з інтелектуальними порушеннями»; «Засвоєння граматичної будови мовлення дітьми із особливими освітніми потребами (ООП)»; «Загальні рекомендації щодо навчання та розвитку дітей з порушеннями опорно-рухового апарату»; «Розроблення Індивідуальної програми розвитку: командний підхід»; «Як підготувати і провести корекційне заняття з дитиною з порушеннями слуху дистанційно? Практичні поради»; «Психологічні бар'єри в освітній діяльності дітей з порушеннями зору та стратегії їх подолання» (ІсПП імені Миколи Ярмаченка НАПН України, 2020).

Запропоновано ключові рекомендації і перелік ресурсів щодо організації онлайн-навчання учнів із особливими потребами різних нозологій. 
Дистанційне навчання передбачає не лише впровадження онлайн-уроків, а насамперед підвищення компетентності педагогічних працівників і руйнування суспільних стереотипів щодо освіти таких дітей. 3 цією метою в Інституті розроблено та запроваджено дистанційні курси для підвищення кваліфікації учителів. Загальна чисельність слухачів, які підвищили свій фаховий рівень дистанційно на базі Інституту, становить понад 500 осіб.

Загалом в Інституті традиційно і ліцензовано провадиться підвищення кваліфікації керівних, педагогічних і науково-педагогічних працівників. З 2018 р. розширено ліцензійне замовлення й розроблено нові програми для педагогів, психологів і соціальних педагогів. Зокрема, запроваджено навчальні програми для курсів підвищення кваліфікації педагогічних працівників Інклюзивноресурсних центрів (ІРЦ): «Освітньо-професійна програма підвищення кваліфікації працівників Інклюзивно-ресурсних центрів»; «Технології навчання дітей з особливими освітніми потребами в умовах інклюзивного середовища»; «|ндивідуальна освітня траєкторія дитини з ООП».

На значну увагу в сучасних умовах заслуговує впровадження системи постійного консультування педагогічних працівників щодо здійснення інклюзивного навчання, корекційно-розвивальної роботи, організації особистісно зорієнтованого навчального процесу осіб із особливими потребами тощо, а також відповідне консультування батьків дітей із особливими потребами. Для цього при Інституті створено Психологічний консультативно-тренінговий центр, де надаються освітні послуги, здійснюється науково-дослідна, консультаційна, психодіагностична, психокорекційна та психологічно-тренінгова діяльність. Окрім офлайн, Є можливість отримати і онлайнконсультацію.

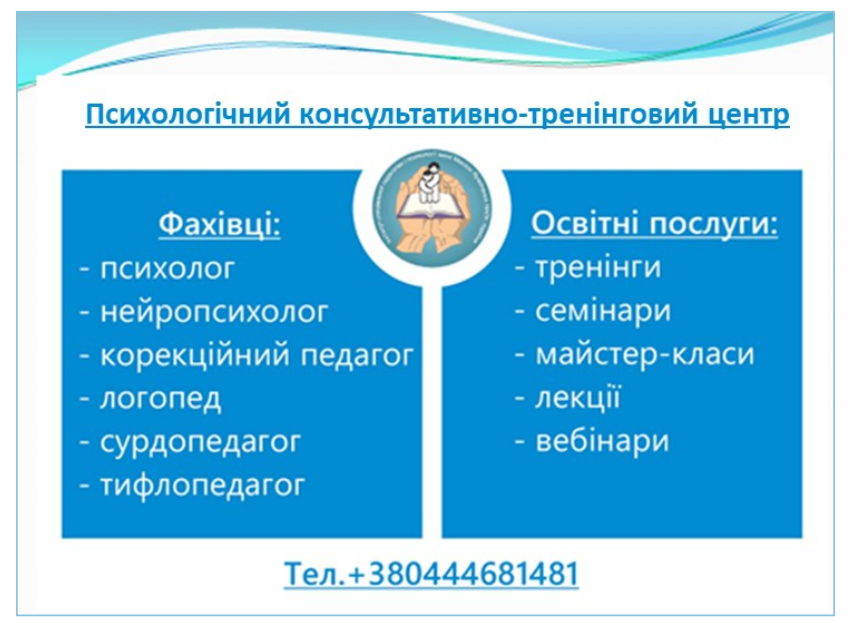

Важливою проблемою, пов'язаною із організацією дистанційної психологічної підтримки, $€$ відсутність системи психолого-педагогічного супроводу в умовах надзвичайних ситуацій родин дітей із особливими освітніми потребами. 3 огляду на це, група вчених Інституту започаткувала проєкт з розроблення цілісної системи надання психологічної допомоги родинам дітей із особливими потребами в умовах кризових ситуацій. На меті - розроблення технології надання психологічної допомоги батькам дітей із особливими потребами, зокрема щодо зняття стресових станів; забезпечення психологічної стабільності; формування імунітету до негативного впливу кризових ситуацій у подальшому, що передбачатиме: індивідуальні та групові заняття з психологом; роботу батьківських груп підтримки; проведення тренінгів і вебінарів; функціонування консультативної телефонної лінії; роботу зі спеціально підготовленими методичними посібниками для психологів і батьків дітей із особливими потребами тощо.

Представлені форми і сучасні технології дистанційної роботи з батьками, на нашу думку, дають змогу різнобічно позитивно впливати на їхній психічний стан і водночас озброюють методично, що принципово важливо для успішного розвитку дітей із особливими потребами саме у кризових ситуаціях.

Практична діяльність потребує таких перспективних розробок:

- вітчизняного інструментарію всеохоплюючої діагностики розвитку дитини з особливим освітніми потребами від 2 до 18 років;

- подальшого розроблення навчальнометодичного забезпечення діяльності інклюзивноресурсних центрів (постанова Кабінету Міністрів України від 12 липня 2017 р. № 545);

- програм раннього втручання і програм розвитку й виховання дітей з особливим освітніми потребами;

- типових освітніх програм і критеріїв оцінювання навчальних досягнень учнів з особливим освітніми потребами (старша школа) тощо.

Тож попереду і науковців, і практиків очікує потрібна і копітка робота з розв'язання означених та інших проблем навчання й виховання дітей 3 особливими потребами, аби останні не відчували будь-яких труднощів, пов'язаних із соціальними чи кризовими ситуаціями. 


\section{СПИСОК ВИКОРИСТАНИХ ДЖЕРЕЛ}

Бабяк, О.О., Баташева, Н.І., Душка, А.Л., Недозим, Н.В., Орлов, О.В., \& Прохоренко, Л.І. (2019). Стандартизачія навчання школярів з порушеннями когнітивного розвитку : навчально-методичний посібник (В.В. Засенко, Л.І. Прохоренко, ред.). Київ: Наша друкарня. https://lib.iitta.gov.ua/718996/

Закон України "Про внесення змін до деяких законів України про освіту щодо організації інклюзивного навчання». (2014). https://zakon.rada.gov.ua/laws/ show/1324-18

Закон України "Про внесення змін до законодавчих актів з питань загальної середньої та дошкільноі освіти щодо організації навчально-виховного проuесу». (2010). https://zakon.rada.gov.ua/laws/ show/2442-17

Закон України «Про забезпечення функціонування української мови як державної». (2019). https:// zakon.rada.gov.ua/laws/card/2704-19

Закон України «Про освіту». (2017). https:// zakon.rada.gov.ua/laws/show/2145-19

Інститут спеціальної педагогіки і психології імені Миколи Ярмаченка Національної академії педагогічних наук України. (n.d.). Головна. http://ispukr.org.ua/

Кабінет Міністрів України. (2016, 14 грудня). Про схвалення Концепції реалізації державної політики у сорері рефрормування загальної середньої освіти «Нова українська школа» на період до 2029 року (988-p). https://zakon.rada.gov.ua/laws/show/988-2016-p

Кабінет Міністрів України. (2018, 21 лютого). Про затвердження Державного стандарту початкової освіти (87). https://zakon.rada.gov.ua/laws/ show/87-2018-ח
Кабінет Міністрів України. (2017, 12 липня). Про затвердження Положення про інклюзивноресурсний чентр (545). https://zakon.rada.gov.ua/ laws/show/545-2017-п

Міністерство освіти і науки України. (2020а, 7 серпня). Моніторинг НУШ. Результати та рекомендаиії. Перший еman, 2019 - 2020 pp. https://cutt.ly/bgl|GnT

Міністерство освіти і науки України. (2020b, 29 липня). Про підготовку закладів освіти до нового навчального року та опалювального сезону в умовах адаптивного карантину (1/9-406). https:// osvita.ua/legislation/other/75378/

Міністерство освіти і науки України. (2020с, 5 серпня). Щодо організації роботи закладів загальної середньої освіти у 2020/2021 навчальному році (1/9420). https://mon.gov.ua/ua/npa/shodo-organizaciyiroboti-zakladiv-zagalnoyi-serednoyi-osviti-u20202021-navchalnomu-roci

Національна академія педагогічних наук України. (2020, 27 серпня). Учені НАПН України - українським вчителям [Відео]. ҮouTube. https:// www.youtube.com/watch?v=HvOGb800OTw

Zasenko, V., Onufriieva, L., Chaikovska, O., Prokhorenko, L., \& Sadova, M. (2020). Ecocentric and anthropocentric settings as determinants of youth social maturity and eco-culture development. International Journal of Psychosocial Rehabilitation, 24(6), 13079-13091. https://doi.org/10.37200/IJPR/V24I6/PR261274

Zasenko, V., \& Prokhorenko, L. (2018). Educational development priorities for people with special needs in Ukraine. Education: Modern Discourses, (1), 161-166. https://doi.org/10.32405/2617-3107-2018-1-15

\section{«SPECIAL CHILDREN» IN A SPECIAL SCHOOL YEAR \\ Scientific report at the web conference "The NAES of Ukraine Researchers to Ukrainian Teachers", August 27, 2020}

\section{Viacheslav Zasenko}

DSc in Pedagogy, Professor, Full Member (Academician) of NAES of Ukraine,

Director, Mykola Yarmachenko Institute of Special Pedagogy and Psychology of

the National Academy of Educational Sciences of Ukraine, Kyiv, Ukraine

Lesya Prokhorenko

DSc in Psychology, Senior Researcher, Deputy Director for Research,

Mykola Yarmachenko Institute of Special Pedagogy and Psychology of

the National Academy of Educational Sciences of Ukraine, Kyiv, Ukraine

Abstract. The general aspects of the education system reforming for people with special needs in Ukraine are briefly outlined; the key ways of modernization are enlightened; the positive changes in the educational sphere are characterized. It is stated in the report that the education system in Ukraine is being reorganised to conform it to the requirements of a market economy and open democratic society on enabling equal access to quality education for all children with special educational needs. The purport of education is seen as a basic tool for transforming the whole system, including special education, on the competence-based principles. From the competence-based point of view, the concretisation of school subjects' quantity is not a special education aim. Instead, the identification of learning outcomes that are nationally significant and outlined, in particular, in the state standards implemented in Ukraine, is the goal. The main approaches and components of the Concept of the New Ukrainian School are described and their influence on reforming the education system of people with special needs is determined. The range of issues requiring urgent solutions concerning the psychological and pedagogical, corrective, and developmental support of children with special needs are outlined.

Keywords: education sphere reforming; Mykola Yarmachenko Institute of Special Pedagogy and Psychology of NAES of Ukraine; children with special educational needs. 